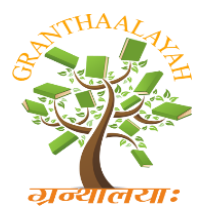

INTERNATIONAL JOURNAL OF RESEARCH GRANTHAALAYAH

A knowledge Repository

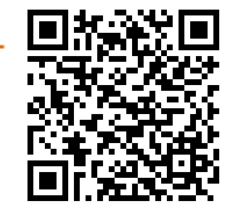

Management

\title{
A STUDY ON JOB SATISFACTION OF EMPLOYEES WITH THE USE OF INFORMATION TECHNOLOGY (IT) IN CO-OPERATIVE SECTOR
}

\author{
Dr. K. Munusamy ${ }^{* 1}$ \\ ${ }^{* 1}$ Post-Doctoral Fellow, Department of Commerce, Periyar University, Salem, TamilNadu, \\ INDIA
}

\begin{abstract}
The Information Technology (IT) must be an integral part of our life and organization strategy. IT needs are increasing day by day and today every person is intending to be IT oriented. Today in big organization IT can be applied in Production, Marketing, Accounting, Finance, Operation Management, Customer Services, Stocking, flow of goods, Human Resource Management (HRM) etc., Today, small enterprises and petty shops also apply IT on a scale according to their need. At present day, IT wings have embraced various departments such as Railway, Transport, Health care services, Educational institutions, Postal services, Banks, Co-operative department, supermarkets etc. There is greater need for use of IT in cooperative sugar mills. IT in co-operative banks is sine quo non to bring about a favorable change in the climate and culture of this bank. IT solutions can help us take problems in core areas of governance and co-operative banks.

IT has a lot of influence on Co-operative banks. The success of IT in co-operative banks depends upon the awareness of employees about the same. They make very limited use of IT. The employees are also not trained in IT. Role of IT in co-operation, there is no study on the opinion of the employees on the use of IT, various problems in selected hardware and software and factors influencing in co-operative banks. It is based on survey of the opinions of employees on the IT, various problems in selected hardware and software and factors influencing the same. This questionnaire contained questions relating to the extent of their satisfaction and benefits of using IT in co-operative banks. 350 employees co-operative banks have been selected at random using lots from the list of employees provided by the respective co-operative banks. This study is an attempt to use of IT in co-operative banks in Salem district. The study highlights the benefits derived by the co-operative banks employees in IT co-operative banks operations. The study will also help to improve the performance of cooperative banks.
\end{abstract}

Keywords:

Use of IT in Co-operative banks, Employees benefits, Employees satisfaction, Hardware and Software problems of Co-operative banks. 
Cite This Article: Dr. K. Munusamy, "A STUDY ON JOB SATISFACTION OF EMPLOYEES WITH THE USE OF INFORMATION TECHNOLOGY (IT) IN CO-OPERATIVE SECTOR" International Journal of Research - Granthaalayah, Vol. 4, No. 6: SE (2016): 57-72.

\section{INTRODUCTION}

We are living in the Information Technology (IT) age. Today world is passing through the era of IT. The IT must be an integral part of our life and organization strategy. Modern day communication service exchange includes electronic mail (e-mail) facsimile transmission, bulletin board service, videotext, voice systems, voice message system and teleconferencing etc. Today e-mail technology enables computer users to send and receive simple messages instantly, documents and reports such as daily, weekly, monthly and annual performance reports created by standard word processing, spreadsheet database, software and even sound animation files.

IT is a basic resource in today's society. Without IT people cannot live in the society. Today most people are sending and receiving the messages through e-mail and internet and it reduces the opportunities of face-to-face communication. Any type of information (or) message can fly round the globe at a fraction of a second through technology tools. IT needs are increasing day by day and today every person is intending to be information technology oriented. Use of IT for generation, storage and retrieval processing and communication of information for improving the effectiveness of an office, which in turn helps to realize the objectives or business functions of the organization in an efficient and competitive manner.

Computerized societies means much more than merely making use of some machines. Computerization means the use of computers in thinking, planning and various electronic data processing devices which are used to record, share process, summary and control activities. The objective of computerization (or) mechanization in India is not to replace man with machine or computer. Rather the objective is to make work-life more meaningful. In fact, this will only reduce the workload involved in the routine work.

IT in co-operative sector is sine quo non to bring about a favorable change in the climate and culture of the societies and in the attitude of personnel at all levels for a smooth implementation of IT plan. Now-a-days computers have simplified the workload in co-operatives and other offices and it supplies useful and accurate information in a very short time. In order to make the co-operative sector a strong one this device must be utilized in all the co-operative societies in India as early as possible. In the year 1989 National Co-operative union of India introduced the National Co-operative Data Bank for various Co-operative institutions' use. This facility can be utilized by the other co-operative societies to strengthen their information base by using the computers in their operations.

\section{Co-operation}

Co-operation is the voluntary association of persons for doing business, the basis of association being equality and the object, the satisfaction of a common need viz., the economic improvement of themselves. Co-operation means working together. Co-operative organization is ultimately a small man's organization. Today co-operation is a world-wide movement. The Indian cooperative movement is the largest in the world. Through its main objective of "self help through 
mutual help" a co-operative organization can eliminate middlemen, enjoy large scale economies and can minimize costs through the active participation of all the members.

"The Co-operative movement in India is the largest in the world. Now it has completed a century. There are 5,45,354 co-operative societies functioning at all levels with 236.23 million of membership and share capital of Rs. 1,98,542.50 million". The co-operative sector in our country has developed and spread its activities and operations in all spheres of economy like agriculture, poultry, dairy, fisheries, hand looms, banking, sugar, spinning, co-optex and consumer cooperatives etc., Today co-operatives expand their wings not only to agriculture production but also as food processing sector. Recently they have started co-operative courier service also. Today co-operative movement has emerged as one of the largest movements in the world. IT provides information on significant contributions made by various state as well as primary level co-operatives in various agriculture and allied sectors also. Co-operative Societies set one of the finest examples of successful integrated rural development through people's participation.

\section{Information Technology (IT)}

IT has become a vital component of successful business organizations. There are no big organizations at present day without using IT. Today in big organization IT can be applied in Production, Marketing, Accounting, Finance, Operation Management, Customer Services, Stocking, flow of goods, Human Resource Management (HRM) etc., Today, small enterprises and petty shops also apply IT on a scale according to their need. IT is playing strategic role in organizations in terms of creating new methods of business as well as opportunities for new businesses. Such as E-commerce, E-Banking, E-Actions and E-services etc., IT solutions can help us take problems in core areas of governance and sectors.

IT refers to the paperless exchange of business information or documents such as purchase orders, sales price, invoices and remittance advices via computer to computer in standard formats. Any communication is an exchange of data between two computers with a few clicks of the mouse. At present day, IT wings have embraced various departments such as Railway, Transport, Health care services, Educational institutions, Postal services, Banks, Co-operative department, supermarkets etc.

IT can help to find solutions to management problems like saving time, money, energy, increasing number of members or customers minimizing paper work, members or customers waiting time in queues and good work of efficiency etc., IT can handle most advanced computing systems and computing devices. All citizens can go to the window, pay the electricity bill, water bill, telephone bill, house tax bill, medical bill, take a driving licence, get the driving licence renewed, apply for a passport, access land records and get needed information through technology way.

\section{Information Technology in Co-operative Sector}

Today co-operative societies can gainfully utilize computers in development work. This system is very useful in mechanized accounting, data processing and communication system. Above all the expectations of members and customers in terms of speed, quality and convenience of service have gone up. Today with global scenario the main concern of co-operative sector is the use of IT applications in new economic activities. Moreover the co-operatives like IFFCO, KRIBHCO, 
co-operative Dairy, Sugar co-operative and Co-operative bank that have provided emphasis to technology transfer have shown their competitive strength. The computerization in PACS in many states has also been undertaken to support the policy makers in decision making process.

Management Information System (MIS) ensures timely flow of information and proper management of data generated in the co-operative sector which are improvements necessary for effective project monitoring. "Thus a scheme for computerization was introduced in 1984-85 with the objective of motivating federations of banks to go in for computerized MIS. Under this scheme National level federations, State level federations, state level co-operative banks implementing National Co-operative Development Corporation (NCDC) project and District level co-operative societies have been benefited". MIS is an important tool for management in all types of enterprises. The co-operative societies irrespective of their size and structure need to develop their MIS to make the organization more functional and flexible. Co-operatives aim to achieve dramatic improvements in critical, contemporary measures of performance, such as cost, quality, services and speed etc. The advantage of computers has made storing, retrieving and analyzing data easy. The use of computers to unnecessary office wastages and expenses should be reduced. There is greater need for use of computers in co-operatives.

In India in the early 1970 s emphasis was given to education and training for the promotion of cooperative enterprises. "Computerization of agricultural co-operatives started 10 years ago in Kerala state and $100 \%$ of primary agricultural co-operatives have been computerized and simplified their work".

IT has a lot of influence on Co-operatives. It ensures quick services with low transaction cost of the members or customers. The success of IT in co-operatives depends upon the members'/customers awareness about the same. IT based solutions for any business has become a common phenomenon in today's age of computers. The co-operative sector has also emerged as one needing computerization. "Computerization of co-operative banks in all states is a very difficult task. Very few states like Maharashtra, Karnataka, Gujarat and Goa are leading in computerization. Mostly computerized urban co-operative banks have on-line branches and have been successful in taking almost all the operational activities".

The Urban co-operative banks are leading in IT implementation but State and District Cooperative Banks are still lagging in computerization drive and are still in infancy stage in most of the states in the country. "The Urban co-operative banks in Maharashtra have started their customer services through telebanking inter branches transactions and providing 24 hrs services through ATMs". In order to improve the performance of co-operatives computerization of all their transactions is a must to cope up with the ongoing revolutionary changes in banking systems such as internet banking, ATMs, anywhere banking and any time banking etc., Hence steps should be taken to introduce computerization at all levels in all co-operatives. IT helps to increase the productivity of existing co-operatives of poor formers. Billing and payment collection will be streamlined through creation of "Smart Cards" with electronic accounts of farmers dues and revenues which can be used to pay bills and purchase consumer products at cooperatives and other stores. 
Information and Communication Technology (ICT) is changing the way $21^{\text {st }}$ century companies, industries operate, Transport Corporations, Co-operative societies bringing considerable benefits to both employees and members. ICT should be adopted to cut across urgent need to all small and medium sectors in future. The introduction of modern ICTs in co-operatives can significantly improve results through facilitating collection, analysis, storage and reporting of information much faster and more accurately than could be accomplished using manual systems.

"The co-operative movement in India has a long history of century with more than 5.49 lakhs cooperatives". The leading co-operatives in India have brought about changes in rural life. The future development of co-operative movement will depend upon the proper and effective communication planning and ICTs. India among the developing nations has always adopted innovative approach in the adoption of new ICTs. ICTs can be used as an effective tool for rural development through co-operative movement. An example is the adoption of ICT by a rural community in the Warna wired village project (WWVP) District Kolhapur, Thasil Panhala in the State of Maharashtra, India.

\section{STATEMENT OF THE PROBLEM}

It is a general misconception that co-operative sector cannot render the same services as private sector. The co-operative sector has contributed more significantly to the growth of the economy. Since, 1904 co-operative sector has registered a colossal growth and helped to attain national global economy. Individuals in the organization will always be responsible for giving services in both forms of ownership. It is the democratic management and development of individuals that make the difference in the form of ownership.

IT will help the co-operative sector not only in servicing but also in various other areas of their operations such as cash management, credit management, Human resource management, sale force functions, personnel functions and ancillary business functions etc. Hence, with an accuracy of information, improved efficiency, image of society in India will definitely improve if the co-operative society modernizes itself. It is true that age old systems such as Typewriting have inherent weaknesses and turn out low volumes of work. The co-operative sector can substantially reduce delay by adopting new technology in operations. This attitudinal attribute needs to be positively reciprocated by the co-operative staff by timeliness in services and friendly disposition.

The quality of co-operative sector personnel depends not only on the quality of intake of personnel but also on the quality of training programmes imparted to them. Training programmes assume a lot of significance in the areas where developments take place rapidly and co-operative technology is undoubtedly one such area. The co-operative sector will have to train their staff to make effective use of technological facilities available to them. Again the fresh postgraduates have little awareness on technological changes along any work experience on IT. Eg. Urban cooperative banks. Hence, the conditions of success of the co-operative officers are overburdened with routine internal work. With increased use of IT and computers, much of the routine workload can be reduced with an added advantage of speed and accuracy. This will not only free the officers for the business development work but will also go a long way in inculcating a sense of belonging to the organization in the employees and will give them more job satisfaction and 
better opportunities for self-development. Today is the age of IT. Enterprises both in the public and private sectors have improved their competitive ability by exploiting IT to the maximum extent. But co-operatives have not done so. They follow the traditional method of information system through papers normally. They make very limited use of IT. The employees are also not trained in IT. This limited use of IT reduces the competitive strength of co-operative societies. This state of affairs leads to the following questions:

i. To what extent co-operative societies utilize IT?

ii. To what extent the employees of co-operative societies are aware, trained and make use of IT?

iii. What are the factors influencing their selected co-operative societies?

This study is an attempt to find answers to the above questions in selected big co-operative societies in Salem District.

\section{SCOPE OF THE STUDY}

The study is limited to the opinions of employees is main constituents of the co-operative societies employees as to the benefits and probable improvement of the co-operative societies, Information Technology (IT) can bring in. The study is not concerned with functioning and working of the co-operative societies.

\section{OBJECTIVES OF THE STUDY}

The objectives of this study are as follows:

1) To assess the extent of use of information Technology (IT) in selected co-operative societies.

2) To assess the opinion of employees of co-operative societies on the extent of use of IT in their co-operative societies.

3) To assess the various factors influencing the selected co-operative societies.

4) To study the benefits of employees to use of IT in co-operative societies.

5) To offer suggestions for making full use of IT in co-operative societies.

\section{REVIEW OF LITERATURE}

The review of literature related to this study reveals that though there are plenty of literature on IT, co-operation and role of IT in co-operation, there is no study on the opinion of the employees on the use of IT in co-operative societies. This study is an attempt to fill this gap. It is based on survey of the opinion of employees on the IT and computerization and factors influencing the same.

\section{Hypotheses}

The main group consists of employees who play a major role of co-operative societies, relating to the use of IT. This group should be aware of the use of IT in their respective co-operative society. Therefore in this study the opinions of employees relating to the use of IT are reviewed. Therefore hypotheses relating to employees have been framed. Employees play a major role in the use of IT. It is they who handle the IT related devices such as computers, internet, email, website etc. They should not only be aware, but also be trained in the use of these devices. 
Therefore this study makes a review of their training also, besides surveying their knowledge, opinion, etc. In tune with the objectives relating to employees the following hypotheses have been formulated and tested in the study. There is no association between the level of satisfaction with the use of IT and knowledge of co-operation, knowledge of the structure, working and management of own society, co-operative education, employee identification, employee satisfaction and knowledge of IT.

\section{RESEARCH METHODOLOGY AND TOOLS}

The study is empirical research based on survey method. The main purpose of the study is the measurement of the abstract variable "use of information technology" and identifies the factors influencing the use of IT in co-operative societies through statistical treatment. The survey was conducted Primary data through questionnaires from employees of co-operative societies. Questionnaires were supplied to the employees of co-operative societies. The questionnaire contained questions relating to the use of IT for various purposes and benefits of use of IT. Scales relating to Satisfaction with Use of IT, Knowledge of co-operation, Knowledge of IT, etc. were also constructed and included in the questionnaire. The questionnaire also contained personal information. These questions relating to how to use the computers or IT their opinions and suggestions to improve the use of IT for the progress of co-operative societies were asked. Thus the study is also expost facto. The researcher had personal discussion with the officials of co-operative societies. He personally contacted the selected employees applied to questionnaires for collecting primary data. The following tools were constructed after the formulation of the problem.

\section{Questionnaires for Employees}

Questionnaires were used to collected data from employees of co-operative societies. This questionnaire contained questions relating to the extent of their satisfaction with the computer training programmes, satisfaction and benefits of using IT in co-operative society. It was used to measure knowledge of co-operation and other qualitative variables also such as knowledge of own society, education, employee satisfaction and knowledge of IT. Suggestions for effective use of IT for better performance of co-operative societies were also sought.

\section{Pilot study and pre-testing}

Pilot study was conducted during the month of August 2015. In the pilot study the questionnaires was pre-tested and then refined for use in the final study. 25 members and 25 employees were selected for pilot study in the nearby The Salem District Central Co-operative Bank Ltd., On the basis of the pilot study the schedules were refined and the study was redesigned, modified and hypotheses were formulated.

\section{Sampling scheme}

The need for introducing IT based systems and communication is essential in all co-operative societies in order to update their operations and improve their competitive strength. However the scope for introducing such IT and systems is more in the case of big co-operative societies. Therefore while selecting the co-operative societies purposive sampling was followed. Seven big co-operative societies were selected. Thus, The Salem District Central Co-operative Bank Ltd., The Salem Co-operative Sugar Mills Ltd., Mohanur, The Krishnagri District Co-operative 
Spinning Mills Ltd., Uthangarai, The Salem District Co-operative Milk Producers' Union Ltd., The Ponni Co-operative Super Market, Co-optex Salem branch and the Thiruchengode Agriculture Producers Co-operative Marketing Society have been selected. As the Salem District Co-operative Spinning Mills, Salem is not functioning, the Krishnagri District Cooperative Spinning Mill Ltd., has been taken in its place. Similarly Co-optex has its jurisdiction throughout Tamilnadu State. However, as the study is confined to Salem District, its Salem branch alone is taken for study.

Simple random technique was applied is selecting employees for the study. 50 employees from each society have been selected at random using lots from the list of employees provided by the respective co-operative society. Thus 350 employees have been selected from all the seven cooperative societies.

\section{Geographical coverage}

The study covers Salem District. As the Salem District Co-operative Spinning Mill Salem is not functioning and as the need for taking a sample of big co-operative spinning mill was felt essential, the Krishnagri District Co-operative Spinning Mills, Uthangarai was taken for study. Similarly the Salem Co-operative sugar mills Mohanur, which once functioned in Salem District before its bifurcation, now is operating in Namakkal District.

\section{Field work and data collection}

Filed work was carried on by the researcher during the period from December 2015 to January 2016. The study only primary data form employees. Primary data were collected from seven cooperative societies. The study covered 50 employees from each co-operative society using simple random technique. A good rapport was created the employees of co-operative societies before the questionnaires were issued to employees. The questionnaires of the employees constituted the main tools of data collection. Employees were questionnaires in their offices by the researcher generally during their working hours. After each questionnaires were thoroughly checked to ensure accuracy, consistency and completeness.

\section{Data processing}

After data were collected first a thorough check up of the data was made. Vertical editing technique was used for the purpose. The missing details were collected through correspondence to the sample societies using supplementary schedules. As field editing was also followed and scores were assigned to each and every questionnaire, there was no need for repeat questionnaires.

\section{Quantification and measurement of variables and construction of scales and indexes}

One of the objectives of the study was to analyses the factors influencing the use of IT. Scaling technique was adopted for measuring the variables. The general rule followed in constructing these measures was to device precise and relatively simple measures. The questionnaire contained questions, inter alia relating to qualitative variables such as knowledge of cooperation, knowledge of own society, co-operative education, employee identification, employee satisfaction and knowledge of IT. Questions relating to these variables were included in the tool. Answer to each question was given a score. The sum of score was taken as the score for the particular variable. 


\section{Dependent and Independent Variables}

The dependent variable of the study is the "Satisfaction with the use of IT". The independent variables whose influences on the dependent variable were studied include Employees knowledge of co-operation, Employees knowledge of own society, Co-operative Education of Employees, Employees Identification with co-operative society, Employee satisfaction and Employee knowledge of IT.

The Dependent Variable of the employee respondents is the extent of Satisfaction with the use of IT. This variable has been measured with a scale by name Satisfaction with the use of IT scale. The scale contained 40 statements relating to the use of various aspects of IT such as ICT, on line, email, website etc. The responses of the respondents were marked in a 5 point Likert type scale, Highly Satisfied, Satisfied, No Opinion, Dissatisfied, and Highly Dissatisfied. Each response was given score 5,4,3,2 and 1 respectively. The total was taken as the Satisfaction with the use of IT score for each respondent. The scores were taken for further analysis with the categories, Low, Medium and High. The mean and standard deviation were calculated. The respondents with scores mean minus 1 standard deviation were categorized in Low Satisfaction group, those with mean plus 1 standard deviation were taken as High Satisfaction group and employees with scores between these two limits were classified as Medium Satisfaction group. The Independent variables are the knowledge variables such as Knowledge of Co-operation, Knowledge of Own Society, Knowledge of IT, etc. These knowledge variables have been measured with their respective scales and then grouped into Low, Medium and High as explained in the case of dependent variable.

\section{Framework of analysis}

The study has been undertaken to measure the extent of use of IT in co-operative societies. Employees' opinion on use of IT constituted the dependent variable. The responses relating to such opinions of employees were measured on scales constructed. The five point Likert type scale has been applied to compute the scores as explained in the previous section. First mean scores of the factor groups have been calculated. Then standard deviation and co-efficient of variation have been computed to know the extent of variation. Chi-square test has been applied to test hypothesis Regression analysis has been made. Besides this core analysis Friedman's Test using the mean rank of the scores was made in order to ascertain the benefits mostly considered in the use of IT.

\section{LIMITATIONS OF THE STUDY}

The study is limited to the opinion of employees on the extent of use of IT in their respective cooperative societies and the benefits of such use of IT. The entire study is qualitative in nature and quantitative variables have not been taken into consideration because, the impact of use of IT on quantitative factors cannot be segregated. Further it is the opinion of the concerned parties in general, which matters rather than the actual facts. The study is also constrained by the limited extent of technical knowledge of the Researcher in IT. 


\section{MAJOR FINDINGS}

- All the types of co-operative societies $96.9 \%$ of the employee respondents are using computers for operations. The highest users are employees of co-operative bank. Cooperative bank is followed by other co-operative societies.

- Most of the employee respondents (49.4\%) reported that the computerization is in progress in their respective co-operative society while $43.4 \%$ maintained that their society is partially computerized. Only $7.1 \%$ responded that their society is fully computerized.

- All the types of co-operative societies individually as well as collectively the employee respondents with good opinion about the use of computers for operations purpose form the largest group.

- All type of co-operatives very low percentage of (1.1\%) reported that their co-operative societies have Electronic Information Display (EID) and Touch Screen Facilities (TSF).

- Majority (35.7\%) of the employee respondents have reported that their respective cooperative society has a website for itself. However on verification it was found that the co-operative bank has it own website and Co-optex headquarters at Chennai alone has one. Other societies do not have website. They do not know the actual fact.

- All type of co-operative societies (90.9\%) of the respondents use computers for calculation of wages and salary. Employees of co-operative spinning mills form the largest group of respondents with (98\%) using computers for calculation of wages and salary. Therefore we can infer that the employees are at least satisfied with the use of computers for calculation of wages and salary.

- Averages of the employee respondents (50.9\%) are satisfied with the use of computers for preparing ledgers. All the sample employees of co-operative bank are preparing ledger accounts through computers. But minimum use of computers is made by the employees of co-operative supermarket (32\%).

- Majority of sample employees are satisfied with using computers for preparing trial balance and balance sheet. The same is observed individually also except in co-operative milk union, co-operative spinning mills with (37.5\%) and (30.6\%) of the respondents are satisfied, though the satisfied group is the largest in these two types.

- All the types of co-operative societies individually and collectively employees using computers for calculation of profits, dividends and commission who are satisfied with the use of computers for arriving at profit, dividend and commission form the largest group among the respondents. However in the co-operative banks and co-operative spinning mills they do not form the majority while in other types they form the majority.

- Most (61.3\%) of the employee respondents using computers for preparing monthly reports are satisfied with that and $(23.8 \%)$ are highly satisfied.

- Majority (85\%) of the respondents using computers for ascertaining daily collections are either satisfied or highly satisfied with that use.

Chi-square Analysis $\left(\chi^{2}\right)$

- The type of co-operative society and level of knowledge on co-operation, level of Knowledge of Own Society of the employees, level of co-operative education, level of identification with co-operative employees, level of employees satisfaction, are not associated does not hold good. From the analysis it is inferred that there is significant relationship between the type of co-operative society and level of knowledge on co- 
operation, level of Knowledge of Own Society of the employees, level of co-operative education, level of identification with co-operative employees, level of employees satisfaction and the employees of co-operative supermarket possessed the high level of knowledge of co-operation.

- The type of co-operative society and level of knowledge on IT of employees are not associated holds good. From the analysis it is inferred that there is no relationship between the type of co-operative society and level of knowledge on IT.

- The level of knowledge on co-operation of the employees, knowledge of own society of the employees, co-operative education of the employees, employee identification with cooperative society, and level of satisfaction with use of IT are not associated holds good. From the analysis it is inferred that there is no relationship between the level of knowledge of co-operation, knowledge of own society of the employees, co-operative education of the employees, employee identification with co-operative society, and level of satisfaction with use of IT.

- The level of employees satisfaction and level of satisfaction with use of IT are not associated does not hold well. From the analysis it is inferred that there is close relationship between the level employees satisfaction and level of satisfaction with use of IT.

- The gender of employees, age group of employees, Educational qualification of employees, Monthly income level of the employees, Period of service of employees, and level of knowledge on IT of employees are not associated holds good. From the analysis it is inferred that there is no relationship between the gender of employees, age group of employees, Educational qualification of employees, Monthly income level of the employees, Period of service of employees and level of knowledge on IT of employees.

- Employees' knowledge on IT and satisfaction with use of IT are not associated holds good. From the analysis it is inferred that there is no relationship between the employees' knowledge on IT and satisfaction with use of IT.

\section{SUGGESTIONS}

In the study, the following suggestions are offered for improving the level of employees' satisfaction with use of IT in co-operatives societies. These suggestions have been brought out from the discussions the researcher had with the employees and officials of the sample cooperative societies and also out of his own experience and observation.

To provide computer literacy awareness In case, the employees may not be familiar with the level of IT. The employees may not feel comfortable in handling business transactions with their co-operative societies.

Must be provides computer training programme of employees In some cases, the employees of the co-operatives may not be in a position to handle such sophisticated level of technologies because of lack of knowledge or skill Therefore, the top management of the co-operatives should take the necessary steps to provide adequate training to their employees in the use of IT. 
To introduce new technologies Physical location of the co-operatives branches will be less important and possibly irrelevant as new technologies provide wider access to a broad range of new facilities/service.

Enrich knowledge of employees The co-operative societies should also take steps for enhancing the level of knowledge and skill of their employees at all levels. The employees of all levels should be motivated through training on about the new technologies they are going to handle in the future.

Optimal use of IT tools: Owing to their sound capital base private, public and foreign enterprises can invest huge funds for technological developments use the IT tools optimally to their benefit. In comparison with this, the cooperative societies are falling behind in this area due to their poor capital base. This will enable them to invest funds on technological developments which are essential for extending all activities of co-operative societies.

Preventive measures to avoid interruption in computerization: The database of co-operative societies will be accessed by so many members/customers and as such there is more possibility of the database getting corrupted because of virus or some other reasons.

\section{CONCLUSION}

This study is an attempt to extent use of IT in co-operative societies in Salem district. The study highlights the extent of employees' satisfaction of co-operative societies with IT servicers. It also highlights the benefits derived by the co-operative societies employees in IT co-operatives operations. The study will also help the employees' satisfaction of co-operative societies and to improve the performance of their co-operative societies. It is therefore earnestly hoped that the authorities will consider the suggestions recommended herewith so as to improving the efficiency of co-operative societies.

\section{REFERENCES}

[1] Joel Edwinraj. D. "Information technology in Co-operative Banks", Tamilnadu Journal of Co-operation, Vol: 4, No: 11, September- 2004, p.31.

[2] National Co-operative Development Co-operation p.18.

[3] Dr. Vijaya. C "Computers in co-operative Breathtaking", Tamilnadu journal of cooperation, Vol: 88, No: 4, July-1996, p.23

[4] File://IWINDOS/Desktop/samy.

[5] Joel Edwinraj. D. "Information technology in Co-operative Banks", Op.cit p.31.

[6] Joel Edwinraj. D. "Information technology in Co-operative Banks", Ibid. p.30.

[7] Raman R. "Indian Co-operative Movement - A Profile 2004", by National Co-operative Union of Indian, New Delhi, p.32.

[8] Dash. D. K. "Computerization in Urban Co-operative Banks: a case study of Amanath Co-operative Bank Banglore”, Co-operative Perspective, Vol.35, No:4, January-March 2001, p.75.

[9] Dash. D. K. "Innovative Banking through Technology", Madhusudan Institute of Cooperative Management, 2006, p.34. 
[10] Franco Dr. C. Eugine Franco, and Regi. $S$ Bulomine, "ADVANTAGES AND CHALLENGES OF E-COMMERCE CUSTOMERS AND BUSINESSES: IN INDIAN PERSPECTIVE” International Journal of Research - Granthaalayah, Vol. 4, No. 3: SE (2016): 7-13.

[11] Golden, S. A. R. (2015). Regional Imbalance affecting quality of e-banking services with special reference to Tuticorin District-An Analysis. International Journal of Research, 2(3), 788-798.

[12] Golden, S. A. R., \& Regi, S. B. (2015). Satisfaction of Customers towards User Friendly Technological Services offered by Public and Private Sector banks at Palayamkottai, Tirunelveli District. International Journal of Research, 2(3), 775-787.

[13] Golden, S. A. R., \& Regi, S. B. Mobile Commerce in Modern Business Era.

[14] Jayasudha. S. M. "Information Technology in Co-operatives - With Special Reference to Co-operative Banks", Tamilnadu Journal of Co-operation, Vol: 3, No: 8, June - 2003, p.25.

[15] Joel Edwinraj. "Information Technology (IT) in Co-operative Banks," Tamilnadu Journal of Co-operation, Vol: 4, No: II, September - 2004, p. 30.

[16] Joel Edwinraj. D. "Information Technology: The Emerging Driving Force in Cooperative Banks", Co-operative Perspective, Vol: 40, No: 1, April-June - 2005, p.5.

[17] Rajendran. K. "Development of Training Programmes at Vellore Central Co-operative Bank", $\quad$ Tamilnadu Journal of Co-operation, Vol: 5, No: 11, September - 2005, p 21.

[18] Regi, S. B. \& S, A. R. G. (2014). "A DESCRIPTIVE STUDY ON THE ROLE OF CONSUMER PSYCHOLOGY AND BEHAVIOUR IN PRODUCT PURCHASING”. Indian Streams Research Journal, 3.

\section{APPENDIX-I}

\section{Satisfaction with use of IT Scale-Employees}

State your opinion towards the following

Strongly Agree (SA) Agree (A) Undecided (U) Disagree (D) Strongly Disagree (SD)

\begin{tabular}{|l|l|l|l|l|l|l|}
\hline $\begin{array}{l}\text { S. } \\
\text { No }\end{array}$ & Particulars SA A & U & D & SD \\
\hline 1 & $\begin{array}{l}\text { The online facilities can be used for asking general } \\
\text { enquires of co-operatives by the members or } \\
\text { customers }\end{array}$ & 5 & 4 & 3 & 2 & 1 \\
\hline 2 & $\begin{array}{l}\text { The general information about co-operatives can be } \\
\text { obtained through websites }\end{array}$ & 5 & 4 & 3 & 2 & 1 \\
\hline 3 & $\begin{array}{l}\text { Information and Communication Technology (ICT) } \\
\text { can not be used for improving co-operative activities }\end{array}$ & 1 & 2 & 3 & 4 & 5 \\
\hline 4 & $\begin{array}{l}\text { Performance, progress and development of } \\
\text { co-operatives can be put on the website }\end{array}$ & 5 & 4 & 3 & 2 & 1 \\
\hline 5 & $\begin{array}{l}\text { Co-operatives have been networked among } \\
\text { themselves more }\end{array}$ & 5 & 4 & 3 & 2 & 1 \\
\hline 6 & $\begin{array}{l}\text { Networking makes co-operative function mon } \\
\text { effectively }\end{array}$ & 5 & 4 & 3 & 2 & 1 \\
\hline 7 & ICT can provide linkage among co-operatives & & & 1 \\
\hline
\end{tabular}




\begin{tabular}{|c|c|c|c|c|c|c|}
\hline $\begin{array}{l}\text { S. } \\
\text { No }\end{array}$ & Particulars & $\mathbf{S A}$ & $\mathbf{A}$ & $\mathbf{U}$ & $\mathbf{D}$ & SD \\
\hline 8 & Customer can be admitted by co-operatives online & 5 & 4 & 3 & 2 & 1 \\
\hline 9 & $\begin{array}{l}\text { Co-operatives have separate E-mail IDs which are } \\
\text { used by the customers }\end{array}$ & 5 & 4 & 3 & 2 & 1 \\
\hline 10 & $\begin{array}{l}\text { The online facilities can not be used to verify the } \\
\text { customers account }\end{array}$ & 1 & 2 & 3 & 4 & 5 \\
\hline 11 & $\begin{array}{l}\text { The list of customers in the co-operatives can be put } \\
\text { on the website }\end{array}$ & 5 & 4 & 3 & 2 & 1 \\
\hline 12 & $\begin{array}{l}\text { ICT can not be used for attracting customers of } \\
\text { co-operatives }\end{array}$ & 1 & 2 & 3 & 4 & 5 \\
\hline 13 & $\begin{array}{l}\text { Co-operatives can require each customer to maintain } \\
\text { separate E-mail IDs for easy communication }\end{array}$ & 5 & 4 & 3 & 2 & 1 \\
\hline 14 & $\begin{array}{l}\text { Customers problems can be handled more } \\
\text { effectively through the use of ICT }\end{array}$ & 5 & 4 & 3 & 2 & 1 \\
\hline 15 & $\begin{array}{l}\text { The general instructions can be displayed on the } \\
\text { website of co-operatives as well as at the touch } \\
\text { screen at the entrance }\end{array}$ & 5 & 4 & 3 & 2 & 1 \\
\hline 16 & $\begin{array}{l}\text { The customers of co-operatives can download } \\
\text { various applications from their respective websites }\end{array}$ & 5 & 4 & 3 & 2 & 1 \\
\hline 17 & $\begin{array}{l}\text { The customers of co-operatives can make online } \\
\text { payment }\end{array}$ & 5 & 4 & 3 & 2 & 1 \\
\hline 18 & $\begin{array}{l}\text { The dues of the customers can be put through } \\
\text { websites }\end{array}$ & 5 & 4 & 3 & 2 & 1 \\
\hline 19 & ICT cannot be used for filling various forms & 1 & 2 & 3 & 4 & 5 \\
\hline 20 & Services of co-operatives can not be extended online & 1 & 2 & 3 & 4 & 5 \\
\hline 21 & $\begin{array}{l}\text { The Electronic Information Display (EID) can not be } \\
\text { used by co-operatives. }\end{array}$ & 1 & 2 & 3 & 4 & 5 \\
\hline 22 & $\begin{array}{l}\text { The Online Public Access Catalogue (OPAC) can } \\
\text { not be used for the customers }\end{array}$ & 1 & 2 & 3 & 4 & 5 \\
\hline 23 & $\begin{array}{l}\text { The Specimen Scanning Photocopy (SSP) can not be } \\
\text { used by co-operatives }\end{array}$ & 1 & 2 & 3 & 4 & 5 \\
\hline 24 & $\begin{array}{l}\text { Co-operatives can use audio-video conference } \\
\text { facilities to serve the customers }\end{array}$ & 5 & 4 & 3 & 2 & 1 \\
\hline 25 & $\begin{array}{l}\text { The ICT can be used to prepare financial reports of } \\
\text { co-operatives }\end{array}$ & 5 & 4 & 3 & 2 & 1 \\
\hline 26 & ICT can be used for preparing micro level reports & 5 & 4 & 3 & 2 & 1 \\
\hline 27 & $\begin{array}{l}\text { ICT cannot be used to check the valuation of assets } \\
\text { and liabilities of co-operatives }\end{array}$ & 1 & 2 & 3 & 4 & 5 \\
\hline 28 & $\begin{array}{l}\text { The updation of all accounts on day-to-day basis is } \\
\text { possible by using ICT }\end{array}$ & 5 & 4 & 3 & 2 & 1 \\
\hline 29 & $\begin{array}{l}\text { ICT can not be used for assessing the effective } \\
\text { domain of the employees }\end{array}$ & 1 & 2 & 3 & 4 & 5 \\
\hline 30 & $\begin{array}{l}\text { The recruitment of co-operative employees can be } \\
\text { made through the use of ICT }\end{array}$ & 5 & 4 & 3 & 2 & 1 \\
\hline 31 & As and when vacancy arises in any co-operative & 5 & 4 & 3 & 2 & 1 \\
\hline
\end{tabular}




\begin{tabular}{|c|c|c|c|c|c|c|}
\hline $\begin{array}{l}\text { S. } \\
\text { No }\end{array}$ & Particulars & SA & $\mathbf{A}$ & $\mathbf{U}$ & D & SD \\
\hline & $\begin{array}{l}\text { such information can be put on website and } \\
\text { applications can be called for }\end{array}$ & & & & & \\
\hline 32 & $\begin{array}{l}\text { The customers can give feedback about the services } \\
\text { of co-operatives through the use of ICT }\end{array}$ & 5 & 4 & 3 & 2 & 1 \\
\hline 33 & $\begin{array}{l}\text { Training programmes to the employees can be } \\
\text { arranged through online video conferencing }\end{array}$ & 5 & 4 & 3 & 2 & 1 \\
\hline 34 & $\begin{array}{l}\text { Attempts have been made for the computer training } \\
\text { programme for all the employees of co-operatives }\end{array}$ & 5 & 4 & 3 & 2 & 1 \\
\hline 35 & $\begin{array}{l}\text { Co-operatives can send various documents through } \\
\text { on-line facility to all the other branches }\end{array}$ & 5 & 4 & 3 & 2 & 1 \\
\hline 36 & $\begin{array}{l}\text { Co-operatives send all their documents to their } \\
\text { central or apex societies on-line }\end{array}$ & 5 & 4 & 3 & 2 & 1 \\
\hline 37 & $\begin{array}{l}\text { Financial management of the co-operative societies } \\
\text { can be done effectively through the use of ICT }\end{array}$ & 5 & 4 & 3 & 2 & 1 \\
\hline 38 & $\begin{array}{l}\text { ICT can be used for assessing and communicating } \\
\text { the overall financial performance of co-operatives }\end{array}$ & 5 & 4 & 3 & 2 & 1 \\
\hline 39 & $\begin{array}{l}\text { ICT can be used by co-operatives for the overall } \\
\text { management of co-operatives }\end{array}$ & 5 & 4 & 3 & 2 & 1 \\
\hline 40 & $\begin{array}{l}\text { ICT can help in improving the administration of } \\
\text { co-operatives }\end{array}$ & 5 & 4 & 3 & 2 & 1 \\
\hline
\end{tabular}

Sources: Primary Date

\section{Satisfaction with use of IT}

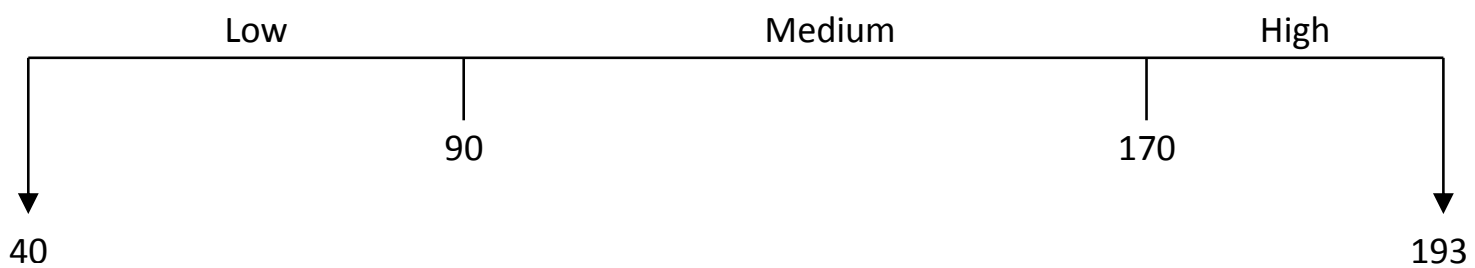

\section{APPENDIX-II}

\section{Regression Coefficients}

\begin{tabular}{|c|c|c|c|c|c|c|}
\hline \multirow[b]{2}{*}{ Model } & & \multicolumn{2}{|c|}{$\begin{array}{l}\text { Un standardized } \\
\text { Coefficients }\end{array}$} & \multirow{2}{*}{\begin{tabular}{|l|}
$\begin{array}{l}\text { Standardized } \\
\text { Coefficients }\end{array}$ \\
Beta
\end{tabular}} & \multirow[b]{2}{*}{$\mathbf{t}$} & \multirow[b]{2}{*}{ Sig. } \\
\hline & & B & $\begin{array}{l}\text { Std. } \\
\text { Error }\end{array}$ & & & \\
\hline \multirow{5}{*}{1} & (Constant) & 83.316 & 5.692 & & 14.637 & 0.000 \\
\hline & $\begin{array}{l}\text { Know on Co- } \\
\text { operation }\end{array}$ & 0.294 & 0.653 & 0.023 & 0.450 & 0.653 \\
\hline & Know. of. Str. & 0.862 & 0.468 & 0.096 & 1.842 & 0.066 \\
\hline & $\begin{array}{l}\text { Co-op. } \\
\text { Education }\end{array}$ & -0.777 & 0.476 & -0.080 & -1.631 & 0.104 \\
\hline & $\begin{array}{l}\text { Emp. } \\
\text { Identification. }\end{array}$ & 0.217 & 0.831 & 0.014 & 0.261 & 0.794 \\
\hline
\end{tabular}




\begin{tabular}{|l|l|l|l|l|l|l|}
\hline \multirow{2}{*}{} & Emp. satisfaction & 0.800 & 0.080 & 0.490 & 9.985 & .000 \\
\cline { 2 - 6 } & Emp. Know -IT & -0.186 & 0.384 & -0.023 & -0.483 & 0.629 \\
\hline
\end{tabular}

Sources: Primary Date

a) Dependent Variable: Overall Satisfaction with use of IT

This appendix shows the coefficients of the regression line. It states that the expected overall satisfactions with use of IT is equal to $\mathrm{Y}=83.316+0.294 \mathrm{X} 1+0.862 \mathrm{X} 2-0.777 \mathrm{X} 3+0.217 \mathrm{X} 4$ $0.186 \times 5+0.800 \times 6$

\section{APPENDIX-III}

\section{Pearson Correlations}

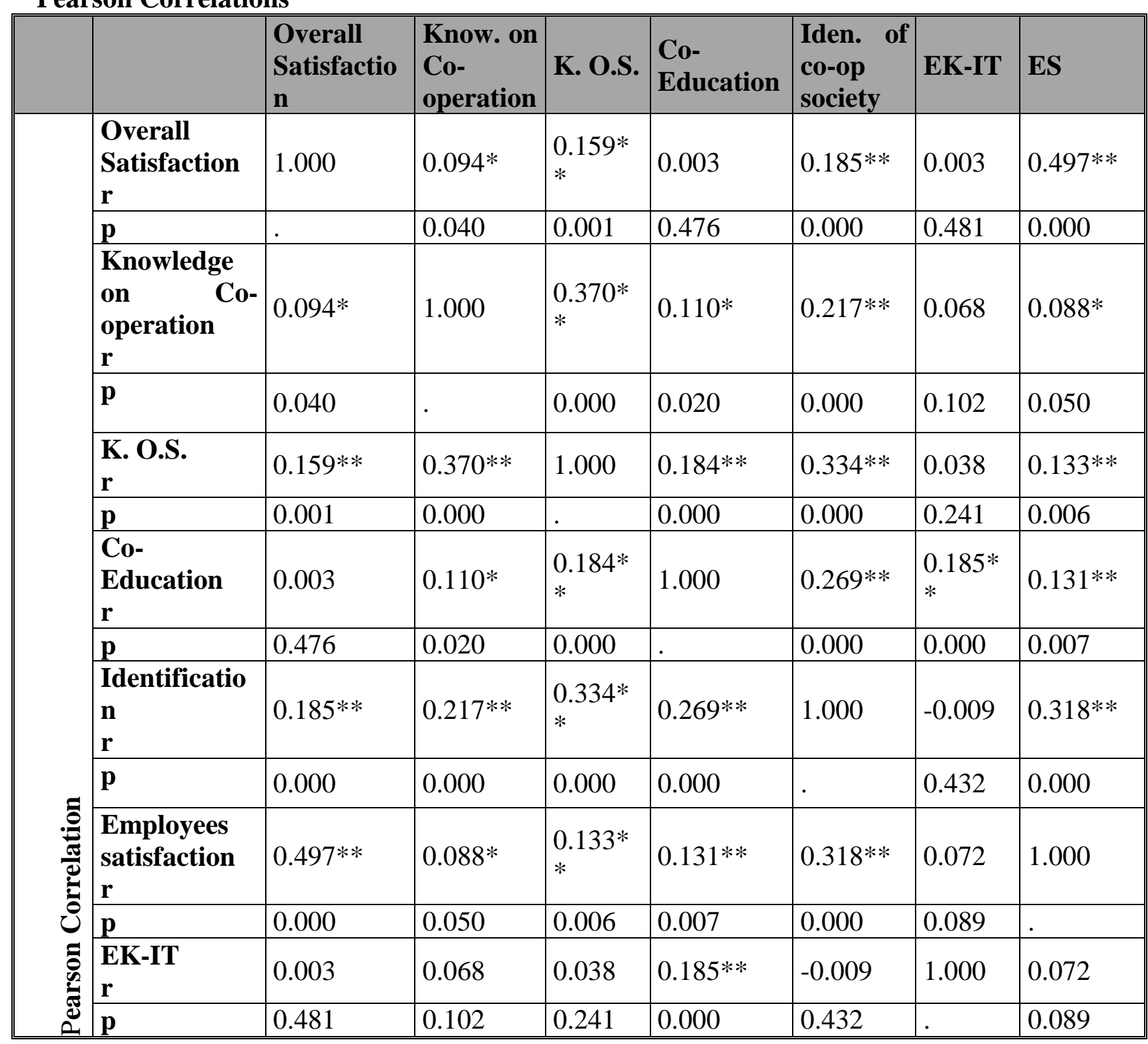

Sources: Primary Date * Significant at 5\% ** Significant at $1 \%$ 